\title{
EHMTI-0224. Occipital nerve stimulation for drug- resistant chronic migraine: increasing experience
}

\author{
PE Bermejo ${ }^{1 *}, C_{\text {del Pozo }}^{2}$, E Parodi ${ }^{2}$, J Ahijado $^{2}$, P Rey ${ }^{2}$ \\ From 4th European Headache and Migraine Trust International Congress: EHMTIC 2014 \\ Copenhagen, Denmark. 18-21 September 2014
}

\section{Introduction}

Although some prophylactic medications have been proposed to treat chronic migraine (CM) there are still many refractory patients and other treatments are warranted. Peripheral nerve stimulation (PNS) of the occipital nerves is a potentially promising therapy for $\mathrm{CM}$ patients.

\section{Aim}

The aim of this study is to evaluate the efficacy and tolerability of PNS of the occipital nerves for the treatment of refractory $\mathrm{CM}$.

\section{Methods}

Twenty one patients ( 8 men, 13 women, average age $52.8 \pm 12.2)$ meeting the IHS criteria for refractory CM were enrolled in this study and implanted with a neurostimulation device near the occipital nerves. The primary endpoint was the reduction in Analogical Visual Scale (AVS). Patient satisfaction, migraine frequency, side effects and reasons for discontinuation were also studied. Significance level was set at $\mathrm{P}<0.05$.

\section{Results}

Headache severity according to the AVS was reduced from $8.9 \pm 0.7$ before PNS to $3.3 \pm 2.8$ after treatment initiation. There was also a significant difference in reduction of number of headache days and $80 \%$ of the patients were satisfied or very satisfied with the procedure. The most common adverse event was persistent implant site pain and only one patient required to be explanted due to inefficacy.

\section{Conclusions}

PNS has been explored as a possible treatment option in selective drug-resistant primary headache disorders and, according to our results, this technique may be effective, safe and well tolerated in treating refractory CM. An increasing experience and a more routine use of these techniques can be forecasted in the near future.

No conflict of interest.

\section{Authors' details}

${ }^{1}$ Neurology, Hospital Puerta de Hierro, Majadahonda, Spain. ${ }^{2}$ Pain Unit, Hospital Puerta de Hierro, Majadahonda, Spain.

Published: 18 September 2014

doi:10.1186/1129-2377-15-S1-G5

Cite this article as: Bermejo et al:: EHMTI-0224. Occipital nerve

stimulation for drug-resistant chronic migraine: increasing experience.

The Journal of Headache and Pain 2014 15(Suppl 1):G5.

\section{SpringerOpen $^{\circ}$}

(C) 2014 Bermejo et al; licensee Springer. This is an Open Access article distributed under the terms of the Creative Commons Attribution License (http://creativecommons.org/licenses/by/2.0), which permits unrestricted use, distribution, and reproduction in any medium, provided the original work is properly cited.
Submit your manuscript to a SpringerOpen ${ }^{\circ}$ journal and benefit from:

- Convenient online submission

- Rigorous peer review

- Immediate publication on acceptance

- Open access: articles freely available online

- High visibility within the field

Retaining the copyright to your article

Submit your next manuscript at $>$ springeropen.com 